\title{
PENGARUH IKLIM KERJA TERHADAP KINERJA PEGAWAI DI KANTOR DINAS PENDIDIKAN KABUPATEN GOWA
}

\section{THE INFLUENCE OF WORK CLIMATE ON EMPLOYEE PERFORMANCE IN THE EDUCATION OFFICE OF GOWA REGENCY}

\author{
Era Prayitna Sainong1), Suarga'2), Kasmawati3) \\ 1,2,3) Universitas Islam Negeri Alauddin Makassar \\ eraprayitnasainong@gmail.com ${ }^{13}$, suargabk@gmail.com²), kasmawati@uin-alauddin.ac.id( ${ }^{3)}$
}

\begin{abstract}
Abstrak
Penelitian ini mengkaji tentang iklim kerja terhadap kinerja pegawai di Kantor Dinas Pendidikan Kabupaten Gowa yang bertujuan untuk mengetahui iklim kerja, kinerja pegawai, dan pengaruh iklim kerja terhadap kinerja pegawai di Kantor Dinas Pendidikan Kabupaten Gowa. Jenis penelitian ini merupakan penelitian kuantitatif dengan menggunakan metode ex post facto. Adapun subjek penelitian ini adalah seluruh pegawai di Kantor Dinas Pendidikan Kabupaten Gowa berjumlah 82 orang dengan menggunakan sampling jenuh. Teknik pengumpulan data menggunakan angket. Teknik analisis data menggunakan teknik analisis statistik deskriptif. Selanjutnya penyajian data menggunakan teknik persentase jawaban dari keseluruhan responden. Hasil penelitian ini menunjukkan bahwa terdapat pengaruh antara iklim kerja terhadap kinerja pegawai di Kantor Dinas Pendidikan Kabupaten Gowa. Dapat dilihat bahwa persentase tertinggi dari kedua variabel tersebut adalah variabel iklim kerja di Kantor Dinas Pendidikan Kabupaten Gowa yakni 67\% dari 82 responden yang menyatakan bahwa iklim kerja di Kantor Dinas Pendidikan Kabupaten Gowa masih sedang atau masih perlu dibenahi. Hal ini mengindikasikan bahwa iklim kerja berpengaruh terhadap kinerja pegawai di Kantor Dinas Pendidikan Kabupaten Gowa.
\end{abstract}

Kata Kunci: iklim kerja, kinerja pegawai

\begin{abstract}
This study examines the work climate on the performance of employees at the Gowa Regency Education Office, which aims to determine the working climate, Employee Performance, and The Effect of Work Climate on Employee Performance in the Education Office of Gowa Regency. This type of research is a quantitative study using the ex post facto method. The subjects of this study were all 82 employees at the Gowa Regency Education Office using saturated sampling. The data collection technique used a questionnaire. The data analysis technique used descriptive statistical analysis techniques. Furthermore, the presentation of the data uses the percentage of answers from all respondents. The results of this study indicate that there is an influence between work climate on employee performance in the Gowa Regency Education Office. It can be seen that the highest percentage of these two variables is the work climate variable in the Gowa Regency Education Office, which is $67 \%$ of the 82 respondents who stated that the work climate in the Gowa Regency Education Office Office is still in progress or needs to be addressed. This indicates that the work climate affects the performance of employees at the Gowa Regency Education Office.
\end{abstract}

Keywords: working climate, employee performance 
How to Cite: Sainong, E. P., Suarga, \& Kasmawati. (2021). Pengaruh iklim kerja terhadap kinerja pegawai di kantor dinas pendidikan kabupaten Gowa. Al asma: Journal of Islamic Education, 3(1), 158-166.

\section{PENDAHULUAN}

Instansi pemerintah adalah organisasi yang merupakan kumpulan orang-orang yang terpilih secara khusus untuk melaksanakan tugas negara sebagai bentuk pelayanan kepada orang banyak. Tujuan instansi pemerintahan dapat dicapai apabila mampu mengolah, menggerakkan dan menggunakan sumber daya manusia yang dimiliki secara efektif dan efesien. Peran manusia dalam organisasi sebagai pegawai memegang peranaan yang menentukan karena hidup matinya suatu organisasi pemerintah semata-mata tergantung pada sumber daya manusianya.

Hal ini memaksa setiap instansi harus dapat bekerja dengan lebih efektif, efesien dan produktif dalam memberikan pelayanan publik tentunya ini akan memacu instansi pemerintahan untuk dapat mempertahankan kelangsungan hidupnya. Hal ini instansi pemerintahan harus memperhatikan aspek sumber daya manusianya. Jadi, manusia dipandang sebagai faktor penentu karena di tangan manusialah inovasi bisa didapatkan untuk mencapai tujuan sebuah instansi pemerintahan (Sinambela, 2017: 333).

Sumber daya manusia sangatlah berperan penting sebagai penggerak seluruh aktivitas suatu instansi. Setiap instansi sepatutnya meningkatkan kualitas kinerja SDM dengan menciptakan iklim kerja yang baik (Diyanti, Hubeis, dan Affandi, 2017). Suatu organisasi mempunyai titik singgung dengan lingkungannya. Menurut Syaiful Sagala (2016: 154), titik singgung itu antara lain keadaan politis, ekonomis dan kebudayaan yang terdapat pada suatu waktu tertentu dalam masyarakat. Proses utama dimensi ini ialah pengaruh, apakah organisasi memengaruhi lingkungan atau lingkungan memengaruhi organisasi. Pengaruh lingkungan organisasi ini terkait dengan subsistem yang mengitarinya. Subsistem administrasi dan susunan organisasi mengacu pada aspek kekuasaan, struktur dan tanggung jawab organisasi. Subsistem informasi dan pengaambilan keputusan berkaitan dengan mekanisme dan ketersediaan informasi yang akurat menghasilkan keputusan-keputusan yang dapat melancarkan dan memelihara kelangsungan organisasi. Subsistem ekonomi dan teknologi mengacu pada peranan biaya dan peralatan yang digunakan dalam melancarkan pelaksanaan tugas-tugas keorganisasian untuk mencapai tujuan secara efektif dan efesien.

Subsistem hubungan antarmanusia mengisyaratkan pentingnya penciptaan relasirelasi yang berdasarkan nilai-nilai manusiawi, etika dan iklim kerja yang kondusif dalam suatu organisasi. Terdapat sejumlah tantangan lingkungan yang khusus dimana para anggota suatu organisasi harus tanggap terhadap lingkungan organisasi. Walaupun lingkungan organisasi itu sendiri adalah dinamis, isolasi dan beberapa tantangan lingkungan akan sangat membantu manajemen dan para anggota organisasi. Kesadaran akan tanggung jawab pada lingkungan dan hendak berinteraksi dengan lingkungan menurut Hicks dan Gullett dalam Syaiful Sagala, akan membantu meyakinkan persetujuan pasar yang penting untuk melanjutkan kelangsungan hidup kegiatan organisasi (Sagala, 2016: 154).

Menurut Steers dan Potter, iklim kerja merupakan karakteristik dari lingkungan kerja yang dapat dirasakan anggota. Iklim kerja adalah hasil dari tindakan yang sudah 
dilakukan karyawan, baik yang dilakukan secara sadar ataupun tidak sadar dan sepertinya mempengaruhi tingkah laku berikutnya. Mereka pun menyatakan keunikan di dalam organisasi terbentuk bersama dengan tindakan-tindakan yang dilaksanakan di dalam manajemen, sehingga tindakan apapun akan menentukan bagaimana iklim kerja organisasi tersebut menjadi faktor yang sangat mempengaruhi tingkah laku pekerja. Menurut Davis dan Keith, iklim kerja organisasi adalah yang menyangkut lingkungan yang ada atau yang dihadapi oleh manusia yang berada dalam suatu organisasi yang mempengaruhi seseorang yang melakukan tugas atau pekerjaan (Sumantri, 2001).

Dessler dalam Agus Pramono (2004: 34), mengatakan bahwa iklim kerja organisasi dengan istilah kehidupan kerja dimana dijelaskan bahwa kualitas kehidupan kerja organisasi tidak sama lagi bagi orang yang berbeda. Kualitas kehidupan kerja atau iklim kerja organisasi yang memadai, berarti keadaan dimana para pegawai dapat memenuhi kebutuhan yang penting melalui organisasi dan kemampuan tersebut akan bergantung pada apakah dalam organisasi terdapat perlakuan yang fair, adil dan suportif terhadap pegawai, kesempatan untuk mewujudkan diri, yaitu untuk menjadi orang yang mereka mampu mewujudkan. Komunikasi terbuka dan saling mempercayai di antara sesama pegawai. Kesempatan bagi semua pegawai untuk berperan secara aktif dalam pengambilan keputusan penting yang melibatkan pekerjaan mereka. Kompensasi yang fair dan lingkungan yang sehat dan aman.

Kinerja pada dasarnya dapat dilihat dari dua segi yaitu kinerja pegawai (individu) dan kinerja organisasi. Kinerja pegawai adalah unjuk kerja perseorangan dalam suatu organisasi, sedangkan kinerja organisasi adalah totalitas hasil kerja yang dicapai suatu organisasi. Kinerja pegawai dan kinerja organisasi memiliki keterkaitan yang sangat erat. Tercapainya tujuan organisasi tidak bisa dilepaskan dari sumber daya yang dimiliki oleh organisasi yang dijalankan pegawai yang berperan aktif sebagai pelaku dalam upaya mencapai tujuan organisasi tersebut. Tercapainya kinerja yang maksimal tidak bisa telepas dari budaya organisasi, efikasi diri pegawai dan peran perilaku pimpinan birokrasi, yang secara sinergi akan melahirkan kepuasan kerja bagi pegawai (Fattah, 2017: 3).

Al-Quran Surah At-Taubah ayat 105 dijelaskan tentang kinerja pegawai, ayat yang dimaksud sebagai berikut:

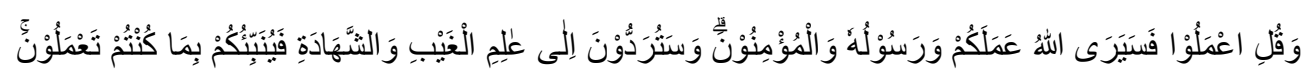

Terjemahnya:

Dan Katakanlah: "Bekerjalah kamu, Maka Allah dan rasul-Nya serta orang-orang mukmin akan melihat pekerjaanmu itu dan kamu akan dikembalikan kepada (Allah) yang mengetahui akan yang ghaib dan yang nyata, lalu diberitakan-Nya kepada kamu apa yang telah kamu kerjakan (Kementerian Agama Republik Indonesia, 2015: 204).

Al-Quran Surah At-Taubah ayat 105 menjelaskan bahwa Allah memerintahkan untuk bekerja dan Allah pasti membalas semua apa yang telah dikerjakan. Yang paling unik dalam ayat ini adalah penegasan Allah bahwa motivasi atau niat bekerja itu harus benar. Sebab jika motivasi bekerja tidak benar, Allah akan membalas dengan cara memberi azab, karena bekerja merupakan kewajiban, maka tak heran jika Umar bin 
Khattab pernah menghalau orang yang berada di masjid agar keluar untuk mencari nafkah. Umar tidak suka melihat orang yang pada siang hari tetap duduk di masjid, sementara sang mentari sudah terpancar bersinar.

Berdasarkan ayat di atas penulis memahami bahwa orang yang bekerja sesuai dengan ajaran islam. Bekerja pada jalur halal dan bukan bekerja dengan pekerjaan yang diharamkan oleh Allah. Allah telah membentangkan bumi dan langit ini sebagai karunia yang teramat besar untuk seluruh umat manusia. Memakmurkan bumi ini melalui bekerja keras, kerja cerdas dan kerja ikhlas, agar pintu keberkahan mengalir ke seluruh penjuru bumi ini. Untuk itu sebagai instansi yang memiliki peran penting maka semua pegawai harus memiiliki kinerja yang baik dalam menjalankan tugas yang diberikan.

Pegawai Kantor Dinas Pendidikan Kabupaten Gowa merupakan unsur pelaksana manajemen yang melayani masyarakat dalam bidang pendidikan. Berdasarkan hasil observasi yang dilakukan di Kantor Dinas Pendidikan Kabupaten Gowa, mulai dari wawancara dan pengamatan langsung. Hasil wawancara pada tanggal 2 November 2020 kepada pegawai yang merasakan langsung iklim kerja di Kantor Dinas Pendidikan Kabupaten Gowa, di antaranya; N: mengatakan bahwa, masih terdapat beberapa pegawai di Kantor Dinas Pendidikan Kabupaten Gowa yang masih berselisih paham sehingga membuat kerjasama antar pegawai dalam menyelesaikan permasalahan di kantor kurang optimal. Pernyataan tersebut berkaitan dengan salah satu indikator iklim kerja tentang hubungan sesama anggota organisasi yang meliputi kerjasama dan komunikasi antar pegawai. A: mengatakan bahwa, lingkungan kerja di Kantor Dinas Pendidikan Kabupaten Gowa sudah memadai, tetapi sepenuhnya masih perlu dibenahi. Pernyataan tersebut berkaitan dengan salah satu indikator iklim kerja tentang lingkungan kerja organisasi yang mengarah pada penerangan, pewarnaan, kebersihan, pertukaran udara, suara/kebisingan, dan kemanaan instansi tersebut.

Berdasarkan pengamatan langsung di Kantor Dinas Pendidikan Kabupaten Gowa, bahwa terdapat lingkungan kerja organisasi yang masih perlu dibenahi dan hubungan sesama anggota organisasi yang belum optimal. Kondisi tersebut yang dapat mendorong pegawai tidak semangat dalam melakukan pekerjaannya, sehingga dapat membuat kinerjanya tidak maksimal. Semua itu berpengaruh dengan iklim kerja yang tidak ideal di dalam sebuah organisasi dalam hal ini instansi pemerintahan. Hal ini sesuai dengan penelitian yang dilakukan oleh Diyanti dkk. (2017) bahwa motivasi dan iklim kerja itu berpengaruh terhadap kinerja tenaga pendidik. Dan juga penelitian oleh (Ulandari et al., 2014) bahwa iklim kerja berperan penting dalam upaya untuk mendukung peningkatan kinerja karyawan.

\section{METODE PENELITIAN}

Jenis penelitian ini menggunakan jenis penelitian ex post facto dengan menggunakan metode kuantitatif. Menurut Sugiyono (2014: 35) metode kuantitatif dapat diartikan sebagai metode penelitian yang berlandaskan pada filsafat positivisme dan digunakan untuk meneliti pada populasi atau sampel tertentu, pengumpulan data menggunakan instrument penelitian, analisis data bersifat kuantitatif atau statistik, dengan tujuan untuk menguji hipotesis yang telah ditentukan.

Adapun populasi penelitian ini adalah seluruh pegawai di Kantor Dinas Pendidikan Kabupaten Gowa sebanyak 82 orang. Mengingat jumlah populasi dalam penelitian ini 
kurang dari 100, maka pengambilan sampel dalam penelitian ini menggunakan sampling jenuh, yaitu teknik yang semua populasi dijadikan sebagai sampel (Sugiyono, 2014b: 124).

Validitas isi instrumen dilakukan dengan memberikan lembar validasi kepada masing-masing pakar ahli (validator) yang berjumlah dua orang. Lembar validasi meliputi aspek petunjuk, bahasa, dan isi angket yang disediakan, kemudian kedua validator tersebut memberi penilaian terhadap instrumen penelitian pada variabel iklim kerja dan variabel kinerja pegawai yang telah didesain.

Validitas pada penelitian ini juga dilakukan pengujian dengan mengorelasikan skor tiap butir dengan skor total yang merupakan jumlah tiap skor butir. Pengujian validitas ini dilakukan dengan bantuan aplikasi SPSS versi 25 for windows, dengan ketentuan apabila nilai $r_{\text {hitung }}>r_{\text {tabel }}$ pada taraf signifikansi $5 \%(0,05)$ maka instrumen dinyatakan valid, begitupun sebaliknya jikanilai $r_{\text {hitung }}<r_{\text {tabel }}$ pada taraf signifikansi $5 \%(0,05)$ maka instrumen dinyatakan tidak valid. Adapaun uji reliabilitas instrumen dalam penelitian ini digunakan untuk menunjukkan sejauh mana suatu alat pengukur dapat dipercaya atau dapat diandalkan. Kaidah yang digunakan adalah apabilanilai r pada Cronbach's Alpha lebih besar dari 0,60 maka variabel dinyatakan reliabel, sedangkan apabila nilai Cronbach's Alpha lebih kecil dari 0,60 maka variabel dinyatakan tidak reliabel. Kemudian teknik analisis data yang digunakan dalam penelitian ini teknik analisis deskriptif.

\section{HASIL DAN PEMBAHASAN}

Hasil analisis statistik deskriptif pada penelitian ini sebagai berikut:

1

\begin{tabular}{lc}
\hline \multicolumn{1}{c}{ Statistik Deskriptif } & Skor \\
\hline Jumlah Sampel & 32 \\
Skor maksimun & 64 \\
Skor minimum & 44 \\
Rata-rata & 58 \\
Standar deviasi & 4 \\
\hline
\end{tabular}

Berdasarkan tabel 1 diperoleh distribusi skor iklim kerja dengan nilai minimum 44, nilai maksimum 64, nilai rata-rata 58 dan standar deviasi 4, sehingga dari tabel distribusi tersebut diperoleh hasil yang ditunjukkan pada tabel di bawah ini.

Tabel 2. Kategorisasi Iklim Kerja

\begin{tabular}{ccccc}
\hline Rumus & Interval & Kategori & Frekuensi & Persentase \\
\hline$x<(\mu-1 \sigma)$ & $x<54$ & Rendah & 13 & $16 \%$ \\
\hline$(\mu-1 \sigma) \leq x<(\mu+1 \sigma)$ & $54 \leq x<62$ & Sedang & 55 & $67 \%$ \\
\hline$(\mu+1 \sigma) \leq x$ & $\leq x 62$ & Tinggi & 14 & $17 \%$ \\
\hline & Total & & 82 & $100 \%$ \\
\hline
\end{tabular}

Tabel di atas menunjukkan bahwa kategori/kriteria tingkat iklim kerja dari 82 jumlah responden terdiri atas beberapa kategori, yaitu: (1) Kategori rendah terdapat 13 responden dengan persentase 16\%; (2) Kategori sedang terdapat 55 responden dengan persentase 67\%; (3) Kategori tinggi terdapat 14 responden dengan persentase 17\%. 
Jadi, dapat disimpulan bahwa tingkat iklim kerja di Kantor Dinas Pendidikan kabupaten Gowa berada pada kategori sedang sebanyak 55 responden (67\%) pada kategori tersebut.

Tabel 3. Hasil Analisis Statistik Deskriptif Kinerja Pegawai

\begin{tabular}{lc}
\hline \multicolumn{1}{c}{ Statistik Deskriptif } & Skor \\
\hline Jumlah Sampel & 82 \\
Skor maksimun & 64 \\
Skor minimum & 46 \\
Rata-rata & 59 \\
Standar deviasi & 4 \\
\hline
\end{tabular}

Berdasarkan tabel 3 diperoleh distribusi skor kinerja pegawai dengan nilai minimum 46, nilai maksimum 64, nilai rata-rata 59 dan standar deviasi 4, sehingga dari tabel distribusi tersebut diperoleh hasil yang ditunjukkan pada tabel di bawah ini:

Tabel 4. Kategorisasi Kinerja Pegawai

\begin{tabular}{ccccc}
\hline Rumus & Interval & Kategori & Frekuensi & Persentase \\
\hline$x<(\mu-1 \sigma)$ & $x<54$ & Rendah & 8 & $10 \%$ \\
\hline$(\mu-1 \sigma) \leq x<(\mu+1 \sigma)$ & $54 \leq x<63$ & Sedang & 52 & $63 \%$ \\
\hline$(\mu+1 \sigma) \leq x$ & $\leq x 63$ & Tinggi & 22 & $27 \%$ \\
\hline & Total & & 82 & $100 \%$ \\
\hline
\end{tabular}

Tabel di atas menunjukkan bahwa kategori/kriteria tingkat kinerja pegawai dari 82 jumlah responden terdiri atas beberapa kategori, yaitu: (1) Kategori rendah terdapat 8 responden dengan persentase 10\%; (2) Kategori sedang terdapat 52 responden dengan persentase 63\%; (3) Kategori tinggi terdapat 22 responden dengan persentase 27\%. Jadi, dapat disimpulan bahwa tingkat kinerja pegawai di kantor dinas pendidikan kabupaten gowa berada pada kategori sedang sebanyak 52 responden (63\%) pada kategori tersebut.

Seluruh pegawai yang dijadikan sampel pada penelitian ini, pada indikator Iklim kerja di Kantor Dinas Pendidikan Kabupaten Gowa berada pada kategori sedang, memiliki frekuensi terbanyak yaitu 55 responden dengan persentase sebesar 67\%. Hal ini menunjukkan bahwa iklim kerja di Kantor Dinas Pendidikan Kabupaten Gowa masih sedang atau masih perlu untuk dibenahi.

Iklim kerja yang dimaksud meliputi lingkungan kerja organisasi seperti kondisi tempat atau ruangan yang berpengaruh (baik langsung maupun tidak langsung) terhadap pegawai dalam melakukan pekerjaan atau aktivitas dalam mencapai tujuan/target, hubungan sesama anggota organisasi seperti membina komunikasi antara sesama anggota organisasi sehingga diperoleh iklim kerja yang baik yang akan berimplikasi pada peningkatan partisipasi kerja, kemudian kepemimpinan organisasi meliputi kemampuan pimpinan dalam mengelola atau mengatur organisasi secara efektif dan mampu melaksanakan kepemimpinan secara efektif pula.

Hal tersebut sejalan dengan pendapat Wirawan dalam Fakhry Zamzam (2012: 28), bahwa Iklim kerja adalah persepsi anggota organisasi mengenai apa yang ada atau terjadi di lingkungan internal organisasi dan kinerja anggota organisasi yang kemudian menentukan kinerja organisasi. Adapun yang dikemukakan Mardiana dalam Yoyo Sudaryo, Agus Aribowo, dan Nunung Ayu Sofiati (2018: 47), bahwa Iklim kerja tersebut 
mencakup hubungan kerja yang terbentuk antara sesama pegawai dan hubungan kerja antarbawahan dan atasan serta lingkungan fisik tempat pegawai bekerja.

Pada indikator kinerja pegawai di Kantor Dinas Pendidikan Kabupaten Gowa berada pada kategori sedang, memiliki frekuensi terbanyak yaitu 52 responden dengan persentase 63\%. Hal ini menunjukkan bahwa kinerja pegawai di Kantor Dinas Pendidikan Kabupaten Gowa masih sedang atau masih perlu di tingkatkan/belum maksimal.

Kinerja pegawai yang dimaksud adalah kemampuan pegawai dalam memenuhi tanggung jawab yang diberikan meliputi kualitas dan kuantitas yang dihasilkan oleh pegawai seperti kecermatan, ketelitian, ketepatan dalam bekerja, volume keluaran dan kontribusi bagi pencapaian target. Selain itu, supervisi dari pimpinan dan kehadiran atau kedisiplinan pegawai serta konservasi yang ditunjukkan oleh pegawai.

Hal tersebut sejalan dengan pendapat Mangkunegara dalam Yusmiar (2014: 77), bahwa kinerja adalah hasil kerja secara kualitas dan kuantiitas yang dicapai seorang pegawai dalam melaksanakan tugasnya sesuai dengan tanggungjawab yang diberikan kepadanya. Kinerja pegawai sangtlah perlu, sebab dengan kinerja ini akan diketahui seberapa jauh kemampuan mereka dalam melaksanakan tugas yang dibebankan kepadanya. Untuk itu, diperlukan penentuan kriteria yang jelas dan terukur, serta ditetapkan secara bersamaa-sama untuk dijadikan sebagai acuan (Sinambela, 2019: 480).

Berdasarkan gambaran mengenai iklim kerja dan kinerja pegawai di Kantor Dinas Pendidikan Kabupaten Gowa yang telah diuraikan sebelumnya, menggambarkan bahwa iklim kerja di Kantor Dinas Pendidikan Kabupaten Gowa berada pada kategori sedang dengan persentase 67\% dari 55 responden dan kinerja pegawai di Kantor Dinas Pendidikan Kabupaten Gowa berada pada kategori sedang pula dengan persentase 63\% dari 52 responden. Dapat dilihat bahwa iklim kerja di Kantor Dinas Pendidikan Kabupaten Gowa lebih mendominasi yakni 55 responden yang menyatakan bahwa iklim kerja di Kantor Dinas Pendidikan Kabupaten Gowa masih sedang atau masih perlu dibenahi, sedangkan pada kinerja pegawai di Kantor Dinas Pendidikan Kabupaten Gowa hanya 52 responden. Hal ini mengindikasikan bahwa iklim kerja memiliki pengaruh terhadap kinerja pegawai di Kantor Dinas Pendidikan Kabupaten Gowa.

Berdasarkan analisis data di atas, dapat dilihat bahwa iklim kerja memiliki pengaruh terhadap kinerja pegawai di Kantor Dinas Pendidikan Kabupaten Gowa. Hal tersebut mendukung teori yang dikemukakan oleh Davis dan Keith dalam Suryana Sumantri, bahwa iklim kerja organisasi adalah yang menyangkut lingkungan yang ada atau yang dihadapi oleh manusia yang berada dalam suatu organisasi yang mempengaruhi seseorang yang melakukan tugas atau pekerjaan(Sumantri, 2001: 50). Demikian juga yang dikemukakan oleh Lijan Poltak Sinambela, dkk. Bahwa kinerja pegawai didefinsikan sebagai kemampuan pegawai dalam melakukan sesuatu keahlian tertentu (Sinambela, 2019: 480). Iklim kerja yang baik dapat mempengaruhi kinerja pegawai saat melakukan pekerjaannya, sehingga untuk memperoleh kinerja yang efektif dan efisien dibutuhkan iklim kerja yang baik.

Hasil penelitian di atas sejalan dengan hasil penelitian sebelumnya yang dilakukan oleh Eko Adi Siswanto (2012: 128) yang menyatakan bahwa iklim kerja dan pengembangan karir berpengaruh positif dan signifikan terhadap komitmen karir. Kemudian hasil penelitian yang dilakukan oleh Nuraini Gani (2019) yang menyatakan bahwa komunikasi interpesonal dan iklim organisasi berpengaruh langsung positif dan 
signifikan terhadap kepuasan kerja dan kinerja pegawai. Hal ini menunjukkan bahwa efektif dan efisiennya kinerja pegawai ditentukan oleh iklim kerja yang dimiliki instansi yang dimana dalam penelitian ini, peneliti fokus pada kinerja pegawai sebagai hal yang dibutuhkan oleh kemajuan instansi dan iklim kerja yang dibutuhkan oleh pegawai dalam melakukan pekerjaanya demi kemajuan instansi.

\section{SIMPULAN}

Pada indikator iklim kerja di Kantor Dinas Pendidikan Kabupaten Gowa berada pada kategori sedang, memiliki frekuensi terbanyak yaitu 55 responden dengan persentase sebesar 67\%. Hal ini menunjukkan bahwa iklim kerja di Kantor Dinas Pendidikan Kabupaten Gowa masih sedang atau masih perlu untuk dibenahi. Pada indikator kinerja pegawai di Kantor Dinas Pendidikan Kabupaten Gowa berada pada kategori sedang, memiliki frekuensi terbanyak yaitu 52 responden dengan persentase 63\%. Hal ini menunjukkan bahwa kinerja pegawai di Kantor Dinas Pendidikan Kabupaten Gowa masih sedang atau masih perlu di tingkatkan/belum maksimal. Dapat dilihat bahwa iklim kerja di Kantor Dinas Pendidikan Kabupaten Gowa lebih mendominasi yakni 55 responden yang menyatakan bahwa iklim kerja di Kantor Dinas Pendidikan Kabupaten Gowa masih sedang atau masih perlu dibenahi, sedangkan pada kinerja pegawai di Kantor Dinas Pendidikan Kabupaten Gowa hanya 52 responden. Hal ini mengindikasikan bahwa iklim kerja memiliki pengaruh terhadap kinerja pegawai di Kantor Dinas Pendidikan Kabupaten Gowa. Bagi pihak instansi, agar kedepannya dapat membenahi iklim kerja dengan baik, agar dapat menunjang kinerja pegawai, sehingga memiliki kinerja yang lebih baik dari sebelumnya. Bagi pegawai, diiharapkan untuk lebih meningkatkan kinerjanya, agar semakin berkualitas. Bagi peneliti selanjutnya, agar melakukan penelitian dengan cakupan materi yang laiinnya, berdasarkan iklim kerja maupun dari segi kinerja pegawai.

\section{DAFTAR PUSTAKA}

Arikunto, S. (2006). Prosedur penelitian suatu pendekatan praktik. Jakarta: Rineka Cipta.

Departemen Agama Republik Indonesia. (2015). Al-Quran dan terjemahannya. Jakarta: CV. Darul Sunnah.

Diyanti, D., Hubeis, M., \& Affandi, M. J. (2017). Pengaruh motivasi kerja dan iklim kerja terhadap kepuasan kerja dan implikasinya terhadap kinerja tenaga kependidikan Institut Pertanian Bogor. Jurnal Aplikasi Bisnis Dan Manajemen, 3(3), 361-372. https://doi.org/10.17358/jabm.3.3.361

Fattah, H. (2017). Kepuasan kerja dan kinerja pegawai. Yogyakarta: Elmatera.

Gani, N. (2019). Kinerja pegawai melalui perbaikan kualitas komunikasi iklim organisasi dan kepuasan kerja pegawai Fakultas Ekonomi dan Bisnis Islam UIN Alauddin Makassar. Jurnal Ekonomi Islam, 6(2), 261-281. https://doi.org/10.24252/lamaisyir.v6i2.11889

Pramono, A. (2004). Analisis keterampilan kerja dan iklim kerja terhadap kualitas pelayanan keperawatan di ruang rawat inap RSU H.Sahudin Kutacane (Tesis). Medan: Program Pasca Sarjana Universitas Sumatra Utara.

Prasetyo, B., \& Jannah, L. M. (2005). Metode penelitian kuantitatif dan aplikasi. Jakarta: Raja Grafindo Persada. 
Sagala, S. (2016). Memahami organisasi pendidikan. Jakarta: Prenada Media.

Sinambela, L. P. (2017). Manajemen sumber daya manusia. Jakarta: Bumi Aksara.

Sinambela, L. P. (2019). Manajemen sumber daya manusia. Jakarta: Bumi Aksara.

Siswanto, E. A. (2012). Analisis pengaruh iklim kerja dan pengembangan karir terhadap komitmen karir di PT Pertamina (Persero) pemasaran wilayah Jateng dan DIY (Skripsi). Semarang: Fakultas Ekonomika dan Bisnis.

Sudaryo, Y., Aribowo, A., \& Sofiati, N. A. (2018). Manajemen sumber daya manusia. Yogyakarta: CV Andi Offset.

Sugiyono. (2014a). Metode penelitian manajemen. Bandung: Alfabeta.

Sugiyono. (2014b). Metode penelitian pendidikan: pendekatan kuantitatif, kualitatif dan $R \& D$. Bandung: Alfabeta.

Sumantri, S. (2001). Perilaku organisasi. Bandung: Universitas Padjadjaran.

Ulandari, L. D., Zukhri, A., \& Suwena, K. R. (2014). Pengaruh iklim kerja terhadap kinerja karyawan pada PT Diva Elektronika Singaraja Tahun 2013. Jurnal Pendidikan Ekonomi Undiksha, 4(1), 1-11. https://ejournal.undiksha.ac.id/index.php/JJPE/article/download/4137/3257

Yusmiar. (2014). Manajemen sumber daya manusia dalam peningkatan kinerja pegawai. Makassar: Alauddin University Press.

Zamzam, F. (2012). Good governance sekertariat DPRD. Yogyakarta: CV Budi Utama. 